\title{
The effects of positive end-expiratory pressure in alveolar recruitment during mechanical ventilation in pigs ${ }^{1}$
}

\author{
Os efeitos da pressão positiva expiratória final no recrutamento alveolar durante a \\ ventilação mecânica em porcos
}

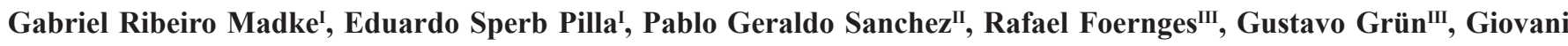 \\ Vendrami ${ }^{\mathrm{III}}$, Eduardo Fontena ${ }^{\mathrm{III}}$, Cristiano Feijó Andrade ${ }^{\mathrm{IV}}$, Paulo Francisco Guerreiro Cardoso ${ }^{\mathrm{V}}$ \\ ${ }^{\mathrm{I}}$ Fellow Master degree, FFFCMPA and Fellow PhD degree UFRGS, Brazil. \\ II Fellow Master degree, UFRGS, Brazil. \\ III Graduate student, FFFCMPA, Brazil. \\ IV $\mathrm{PhD}$ in Pneumology, UFRGS, Brazil. \\ ${ }^{v}$ PhD, Associate Professor, Division of Thoracic Surgery, Department of Surgery, FFFCMPA, Brazil.
}

\begin{abstract}
Purpose: To evaluate the effects of alveolar recruitment based on mean airway pressure (MAP) on pig lungs submitted to thoracotomy through blood gas exchange and hemodynamic parameters. Methods: Twelve pigs weighting approximately $25 \mathrm{Kg}$ were intubated and ventilated on volume controlled ventilation (tidal volume $10 \mathrm{ml} / \mathrm{Kg}$, respiratory rate $16 \mathrm{~min}, \mathrm{FiO}, 1.0$, inspiratory:expiratory ratio $1: 2$, PEEP $5 \mathrm{cmH}_{2} \mathrm{O}$ ). The animals were then randomized into two groups: control and left lateral

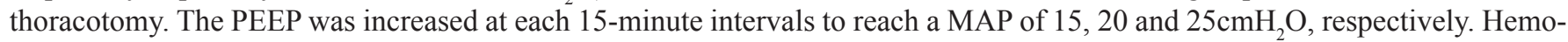
dynamic, gas exchange and respiratory mechanic data were measured immediately before each PEEP change. Results: There were no significant differences between both groups in all parameters analyzed $(P=1.0)$. The $\mathrm{PaO}_{2}, \mathrm{PaCO}_{2}, \mathrm{MAP}$, PAP and plateau pressure were significantly worse at MAP of $25 \mathrm{cmH}_{2} \mathrm{O}$, when compared with the other values of MAP $(P=0.001, P=0.039$, $P=0.001, P=0.016$ e $P=0.027$, respectively). The best pulmonary performance according to the analyzed parameters was observed at MAP of $20 \mathrm{cmH}_{2} \mathrm{O}$. Conclusion: PEEP adjusted to MAP of $20 \mathrm{cmH}_{2} \mathrm{O}$ resulted in best arterial oxygenation, without compromising the venous return, as opposed to MAP of $25 \mathrm{cmH}_{2} \mathrm{O}$, which caused deterioration of gas exchange, hemodynamics and respiratory mechanic.
\end{abstract}

Key words: Respiration, Artificial. Positive-Pressure Respiration. Pulmonary Alveoli. Swine.

\section{RESUMO}

Objetivo: Avaliar os efeitos do recrutamento alveolar baseado na pressão média das vias aéreas (Pmédia) sobre os pulmões de porcos submetidos a toracotomia, através de dados gasométricos e hemodinâmicos. Métodos: Doze porcos machos pesando em média $25 \mathrm{Kg}$ receberam indução anestésica, sendo intubados e ventilados a volume $\left(\mathrm{FiO}_{2}=1.0\right.$, volume corrente=10 $\mathrm{ml} / \mathrm{kg} / \mathrm{min}$, $\mathrm{FR}=16 \mathrm{cpm}$, relação $\mathrm{I}: \mathrm{E}=1: 2$ e PEEP $5 \mathrm{mmHg}$ ). Os animais foram randomizados em dois grupos: controle e toracotomia lateral esquerda. Os valores de PEEP em cada grupo foram aumentados a cada 15 minutos para atingir valores de Pmédia de 15, 20 e $25 \mathrm{cmH}_{2} \mathrm{O}$, sendo coletados dados hemodinâmicos, gasometria arterial e mecânica respiratória imediatamente antes de cada acréscimo do PEEP. Resultados: Não houve diferença estatisticamente significativa entre os 2 grupos em todos os parâmetros analisados $(P=1,0)$. Ocorreu piora significativa da $\mathrm{PaO}_{2}, \mathrm{PaCO}_{2}$, pressão arterial média, pressão da artéria pulmonar e pressão de platô com Pmédia de $25 \mathrm{cmH}_{2} \mathrm{O}$ comparado com os demais valores de Pmédia $(P=0.001, P=0.039, P=0.001, P=0.016$ e $P=0.027$, respectivamente). O melhor desempenho pulmonar pelos parâmetros analisados ocorreu com a Pmédia de $20 \mathrm{cmH}_{2} \mathrm{O}$. Conclusão: As manobras de recrutamento alveolar alteram o desempenho pulmonar e função hemodinâmica independemente da cavidade torácica estar aberta ou fechada. O PEEP ideal para o recrutamento alveolar independente dos grupos estudados foi obtido a uma Pmédia de $20 \mathrm{cmH}_{2} \mathrm{O}$ em relação a todos os parâmetros analisados.

Descritores: Respiração Artificial. Respiração com Pressão Positiva. Alvéolos Pulmonares. Suínos.

\footnotetext{
${ }^{1}$ Research performed at Laboratory of Experimental Surgery Jean Carlo Kohmann, Department of Surgery, Post-graduate Program of Medical Sciences, Federal Faculty of Medicine of Porto Alegre (FFFCMPA), Rio Grande do Sul, Brazil.
} 


\section{Introduction}

Mechanical ventilation has been incorporated into the basic life support for several decades, but numerous potential drawbacks and complications have been identified early in the use of mechanical ventilation ${ }^{1}$.

Artificial mechanical ventilation is used to improve patient's oxygenation with compromised lung function. Such support measures might ultimately cause ventilator-induced lung injury, which includes edema, pneumothorax and rupture of alveolar walls. Ventilator-induced lung injury occurs in $0.5-$ $38 \%$ of all mechanically ventilated patients and in up to $83 \%$ of those with underlying chronic lung disease. The additional mortality rate of patients who develop ventilator-induced lung injury as a complication of mechanical ventilation is as high as $13-35 \%{ }^{1}$.

A large number of animals and clinical studies have shown that mechanical ventilation can worsen preexisting lung injury or produce acute lung injury de novo in previously normal lungs ${ }^{2}$. The postulated mechanisms responsible for ventilator-induced lung injury is the mechanical stress induced by shear forces that might initiate or worsen pulmonary inflammatory processes and alter the alveolar-endothelial barrier, as well as the surfactant function ${ }^{3}$.

In response to concerns about the potential adverse effects of mechanical ventilation, lung protective strategies that limit tidal volumes, plateau pressures and positive airway pressure have been suggested in the literature as alveolar recruitment enhancement strategies. It has been shown in a number of experimental models of acute lung injury that ventilation with high positive end-expiratory pressure (PEEP) attenuates lung injury by reducing the number of atelectasis or edematous alveoli at end-expiration ${ }^{5}$.

Patients with the acute respiratory distress syndrome are particularly prone to overdistention, particularly when conventional tidal volumes are used (10 to $15 \mathrm{ml}$ per kilogram of body weight), since the number of lung units available for ventilation is markedly reduced as a result of fluid accumulation, consolidation, and atelectasis ${ }^{6}$. Ventilation strategies that limit airway pressure and volume often result in hypercapnia and respiratory acidosis, which could ultimately be harmful to extremely ill patients. Nonetheless, observational studies have reported reduced mortality when patients with the acute respiratory distress syndrome undergo ventilation at decreased pressures and tidal volumes ${ }^{7}$.

Amato et al showed that the use of low tidal volume plus moderate/high PEEP and the use of periodic recruitment maneuvers (RM) in patients with acute lung injury and ARDS improved patients' outcomes. Since then, many studies have considered RM as a tool to improve oxygenation and perhaps survival in ARDS ${ }^{8,9}$.

Following such initial enthusiasm, a number of issues have been raised regarding optimal lung recruitment. Many different RM were proposed, and the ideal frequency and duration have not yet been established. A number of experimental models of lung injury have shown that the best RM seems to be the use of mechanical ventilation with low tidal volumes and PEEP adjusted to the lower inflection point in the pressure-volume curve $^{4,10}$. The amount of positive pressure and the length of time that the airway is submitted to such pressure are factors estimated by the mean airway pressure (MAP), that is the pressure required to open de airway during the entire respiratory cycle, corresponding to the pressure that causes alveoli to distend. It also has a relationship with the mean alveolar pressure, and thus with alveolar recruitment ${ }^{11}$.

The objective of this study is to analyze the effects of MAP on gas exchange and hemodynamics in pigs submitted to mechanical ventilation, and compare the findings between animals with a closed chest (control) versus an open chest (thoracotomy), in order to exclude thoracotomy as a confusion factor for further studies on mechanical ventilation.

\section{Methods}

The animals received humane care in compliance with the "Guide for the Care and Use of Laboratory Animals" (National Institutes of Health Publication 85-23, revised, 1985). Twelve pigs weighing $25 \mathrm{~kg}$ in average, received general anesthesia (induction with Ketamine $20 \mathrm{mg} / \mathrm{kg}$ and Xylazine $2 \mathrm{mg}$ / $\mathrm{kg}$ IM, followed by thiopental $10 \mathrm{mg} / \mathrm{kg}$ IV and fentanyl $10 \mu \mathrm{g} /$ $\mathrm{Kg}$ IV). Muscle relaxation was done with pancuronium bromide $(0,15 \mathrm{mg} / \mathrm{Kg}$ IV bolus, followed by intermittent doses of $0,1 \mathrm{mg} / \mathrm{Kg} / \mathrm{h})$. Following induction, the animals were intubated with a $7.0 \mathrm{~mm}$ outer diameter endotracheal tube. Each animal had a pulmonary artery catheter placed percutaneously via the jugular vein. An indwelling arterial and venous line placed in the femoral artery and vein, respectively, for blood sampling and hemodynamic measurements. The animals were ventilated in a volume-cycled, pressure-limited ventilator (Servo 900C, Siemens Elema-Sweden) with a peak inspiratory pressure (PIP) of less than $35 \mathrm{cmH}_{2} \mathrm{O}$, tidal volume of $10 \mathrm{ml} / \mathrm{Kg}$, respiratory rate of 16 breaths/minute, $\mathrm{FiO}_{2} 1.0$, inspiratory: expiratory ratio $1: 2$ and a $5 \mathrm{cmH}_{2} \mathrm{O}$ PEEP. No vasoactive drugs were used in the experiments. Five minutes after stabilization, the animals were randomized into two groups: group 1 (control - no thoracotomy) and group 2 (thoracotomy), in which pigs were submitted to a left lateral thoracotomy and chest tube drainage with posterior close of the wound. In each animal, the PEEP was increased to reach a MAP of 15, 20 and $25 \mathrm{cmH}_{2} \mathrm{O}$ every 15 minutes, respectively. Immediately before each incremental adjustment, the PEEP was returned to a baseline of $5 \mathrm{mmHg}$ for 5 minutes. At the end of the 15-minute observation period of each MAP, hemodynamic data was recorded (mean arterial blood pressureMABP; pulmonary arterial pressure-PAP), arterial blood gas analysis $\left(\mathrm{PaO}_{2}\right.$ and $\left.\mathrm{PaCO}_{2}\right)$ and dynamic respiratory parameters measurements (plateau pressure-Ppl) were obtained.

Statistical analysis was performed using the SPSS12.0 software. Differences between groups were evaluated using ChiSquare test. McNemar Test was used for within the groups analysis of the different values of MAP. Statistical significance was considered for $P$ less than 0.05 . 


\section{Results}

All animals survived the observation period. There were no significant differences between the groups in all parameters $(P=1.0)$. When the values of MABP between MAP 15 $\mathrm{cmH}_{2} \mathrm{O}$ and $20 \mathrm{cmH}_{2} \mathrm{O}$ with MAP $25 \mathrm{cmH}_{2} \mathrm{O}$ were compared, there were significant differences in both groups $(P=0.001)$ (Figure 1).

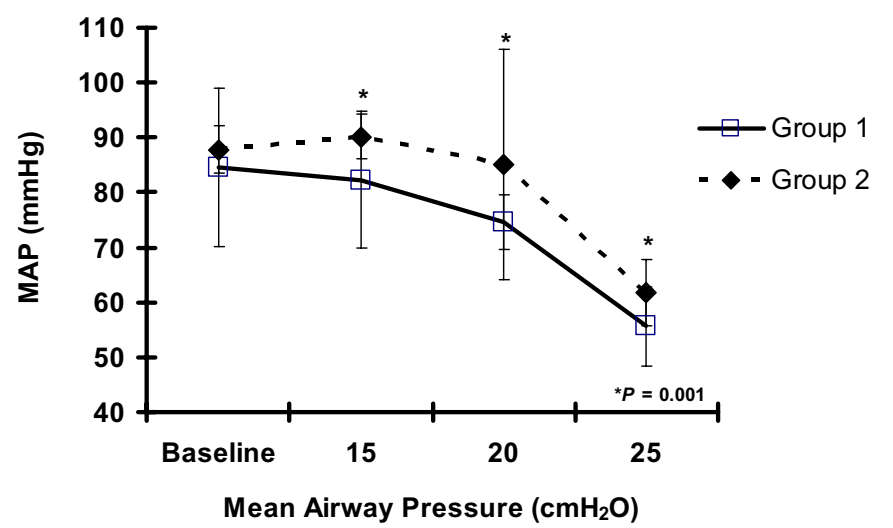

FIGURE 1 - Mean Arterial Blood Pressure: MABP significant lower in MAP $25 \mathrm{cmH}_{2} \mathrm{O}$ when compared with MAP $15 \mathrm{cmH}_{2} \mathrm{O}$ and 20 $\mathrm{cmH}_{2} \mathrm{O}(P=0.001)$

A significant difference was observed when values of PAP between MAP $15 \mathrm{cmH}_{2} \mathrm{O}$ and $20 \mathrm{cmH}_{2} \mathrm{O}$ were compared with the values of PAP in MAP $25 \mathrm{cmH}_{2} \mathrm{O}$ in both groups $(P=0.016$ and $P=0.031$, respectively; Figure 2$)$.

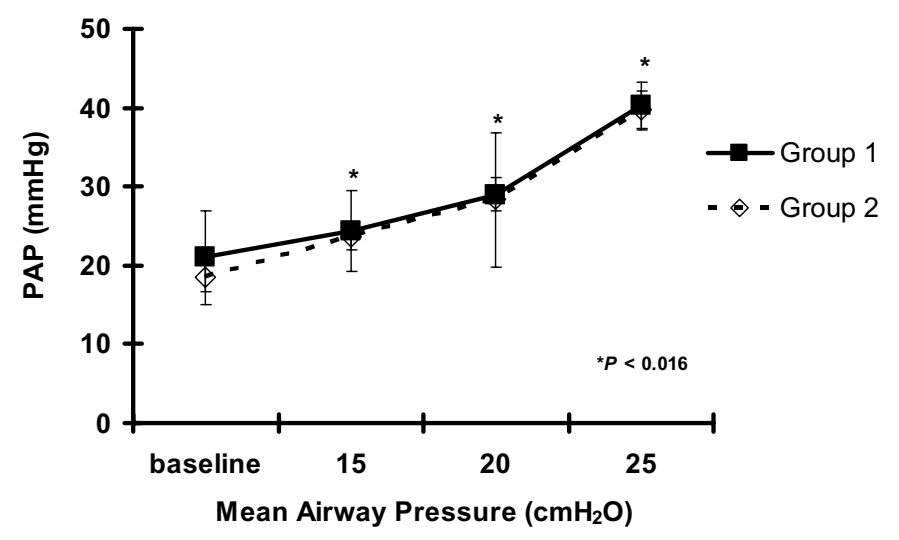

FIGURE 2 - Pulmonary Arterial Pressure: PAP significant higher when values of PAP between MAP $15 \mathrm{cmH}_{2} \mathrm{O}$ and $20 \mathrm{cmH}_{2} \mathrm{O}$ were compared with the values of PAP in MAP $25 \mathrm{cmH}_{2} \mathrm{O}$ in both groups $(P=0.016$ and $P=0.031$ )
The values of $\mathrm{PaO}_{2}$ when MAP was adjusted at $25 \mathrm{cmH}_{2} \mathrm{O}$ were significant lower when compared to all other MAP adjustments in both groups $(P=0.001$, Figure 3$)$.

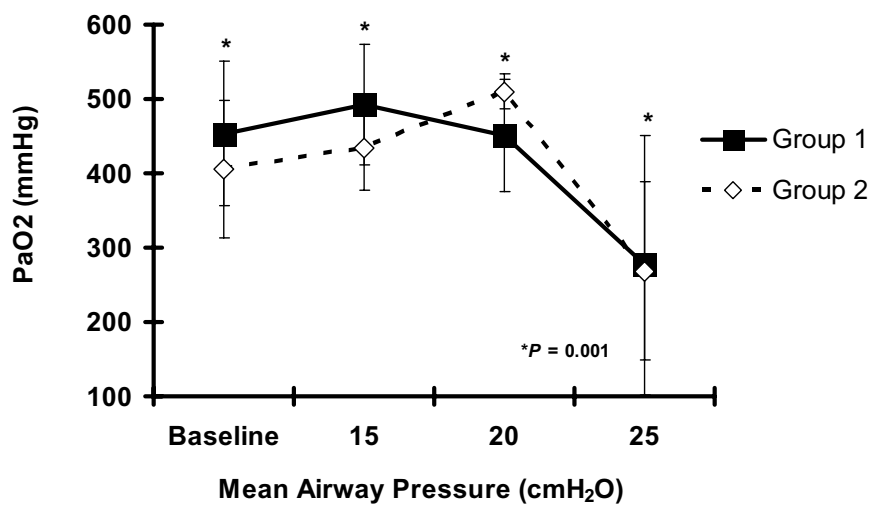

FIGURE 3 - Partial Oxygen Pressure: $\mathrm{PaO}_{2}$ significant lower when MAP was adjusted at $25 \mathrm{cmH}_{2} \mathrm{O}$ were when compared to all other MAP $(P=0.001)$

There was a significant difference between the $\mathrm{PaCO}_{2}$ values when the MAP was $15 \mathrm{cmH}_{2} \mathrm{O}$ when compared to the MAP at $25 \mathrm{cmH}_{2} \mathrm{O}(P=0.039)$, however there was no significant difference between MAP $20 \mathrm{cmH}_{2} \mathrm{O}$ and MAP $25 \mathrm{cmH}_{2} \mathrm{O}$ $(P=0.07)$. When comparing dynamic respiratory measurements, all values of PEEP until MAP $25 \mathrm{cmH}_{2} \mathrm{O}$ did not increase plateau pressure above $30 \mathrm{cmH}_{2} \mathrm{O}$. On the other hand, a MAP $25 \mathrm{cmH}_{2} \mathrm{O}$ caused a significant increase of $\mathrm{Ppl}(P=0.027$, Figure 4).

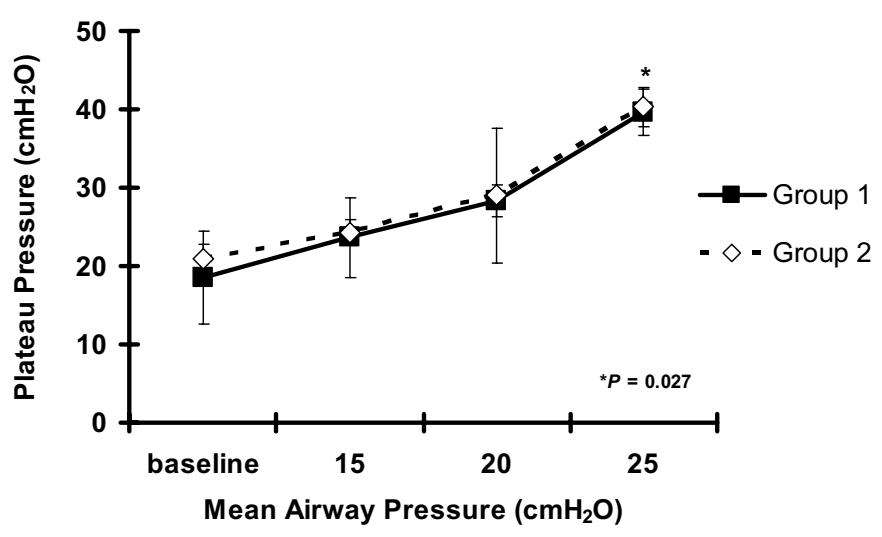

FIGURE 4 - Plateau Pressure: MAP $25 \mathrm{cmH}_{2} \mathrm{O}$ caused a significant increase of $\mathrm{Ppl}(P=0.027)$ 


\section{Discussion}

The primary objective of this study was to develop a new strategy of recruitment maneuver in an animal model of open and closed chest, in to assess the influence of the thoracotomy under different PEEP levels. This technique is easier to use routinely in the clinical setting when compared to the PEEP adjusted to the lower inflection point of the pressure-volume curve. This new strategy is similar to that one based on lower tidal volume and higher $\mathrm{PEEP}^{3,9}$. Our results are similar from those of the literature, showing a good gas exchange and hemodynamic performance in this model of $\mathrm{RM}^{9}$.

According to the literature, recruitment maneuvers yield different effects depending on the type and severity of lung insult, as well as on the use of different combinations of tidal volume and PEEP, either before or after the RM. The beneficial effects of RM were demonstrated mostly in animal models of alveolar collapse induced by surfactant depletion ${ }^{13}$. In animal models of lung injury other than produced by surfactant depletion, the effect of RM on lung function is less evident ${ }^{14}$. Insofar, there has been no consensus on the best level of PEEP for effective lung protection. The ideal PEEP should be high enough to be able to maintain or improve arterial oxygenation as well as low enough to avoid hemodynamic collapse.

We found a significant improvement on arterial oxygenation when PEEP was adjusted to MAP $20 \mathrm{cmH}_{2} \mathrm{O}$. Conversely, when higher MAP $\left(25 \mathrm{cmH}_{2} \mathrm{O}\right)$ was used, it resulted in lower $\mathrm{PaO}_{2}$ and worsened the hemodynamic parameters, resulting in hemodynamic collapse.

RM based on the blood gas analysis alone as a ventilatory strategy has failed to improve outcome in some studies ${ }^{15}$, and there are physiological mechanisms of practical relevance that might explain such findings. In the clinical scenario, ventilator settings are often adjusted to achieve predetermined arterial blood gas values. This approach seems adequate when only oxygenation and carbon dioxide removal are considered. Once the changes on ventilator settings are carried out, one is temped to conclude that an improvement on arterial oxygenation reflects alveolar recruitment, whereas recruitment may indeed be the cause for improved oxygenation. Furthermore the increase in $\mathrm{PaO}_{2}$ may simply reflect the consequences of the changes in the ventilator settings upon hemodynamics ${ }^{15}$.

The increase in intrathoracic pressure resulting from the increments in PEEP can also reduce venous return to the right atrium. The subsequent reduction on right ventricular enddiastolic volume leads to a substantial decrease in cardiac output $^{15}$. In contrast, a decrease in cardiac output may improve the effectiveness of hypoxic pulmonary vasoconstriction, which is seldom taken into consideration. Improved arterial oxygenation may be the result of improved hypoxic pulmonary vasoconstriction after a decrease in venous return rather than a result of alveolar recruitment itself. Indeed, single or periodic sustained increase in intrathoracic pressure can induce adverse hemodynamic effects and compromise cardiac performance in a patient who is already critically ill. Unintentional lung overinflation can increase pulmonary vascular resistance with blood flow diversion from overinflated alveoli to consolidated but perfused alveoli, thus incrementing intrapulmonary shunt ${ }^{16}$. It is therefore advisable to consider gas exchange, hemodynamic parameters and dynamic respiratory mechanics measurements altogether, in order to obtain an ideal alveolar recruitment. We expected the animals in the thoracotomy group to have had an altered intra-thoracic pressure, however no significant differences were observed between the two groups in regards to hemodynamic parameters.

\section{Conclusions}

The PEEP adjusted to MAP of $20 \mathrm{cmH}_{2} \mathrm{O}$ can be used as an "Ideal PEEP", based on improved arterial oxygenation, without any sizeable hemodynamic and respiratory impairment, regardless the presence of thoracotomy. Such findings may potentially represent a practical modality of alveolar recruitment, easily transposed into apply the clinical setting. Such strategy is currently being applied to a pig lung model of severe lung injury as part of an ongoing study of this research line, in which this "Ideal PEEP" will be used in a model of lung injury caused by oleic acid as well as in a lung transplant model of severe reperfusion injury.

\section{References}

1. Ricard JD, Dreyfuss D, Saumon G. Ventilator-induced lung injury. Eur Respir J. 2003; 22:2s-9s.

2. Dos Santos CC, Slutsky AS. Mechanims of ventilator-induced lung injury: a perspective study. J Appl Physiol. 2000;89:1645-55.

3. Slutsky AS. Lung injury caused by mechanical ventilation. Chest. 1999;116:9S-15S.

4. Brower RG, Matthay MA, Morris A, Schoenfeld D, Thompson BT, Wheeler A. Ventilation with lower tidal volumes as compared with traditional tidal volumes for acute lung injury and the acute respiratory distress syndrome: the Acute Respiratory Distress Syndrome Network. N Engl J Med. 2000;342:1301-8.

5. Dreyfuss D, Saumon G. Ventilator-induced lung injury: lessons from experimental studies. Am J Respir Crit Care Med. 1998;157:294-323. 6. Gattinoni L, Presenti A, Torresin, Baglioni S, Rivolta M, Rossi F, Scarani F, Marcolin R, Cappalletti G. Adult respiratory distress syndrome profiles by computed tomography. J Thorac Imaging. 1986;1:25-30.

7. Hickling KG, Henderson SJ, Jackson R. Low mortality associated with low volume pressure limited ventilation with permissive hypercapnia in severe adult respiratory distress syndrome. Intensive Care Med 1990;16:372-7.

8. Amato MBO, Barbas CS, Medeiros DM, Magaldi RB, Schettino GPP, Filho Gl, Kairalla RA, Deheinzeli D. Effect of a protective-ventilation strategy on mortality in the acute respiratory distress syndrome. N Engl J Med. 1998;338:347-54.

9. Amato MBO, Barbas CS, Medeiros, Schettino, GPP, Filho GL, Kairalla RA. Benefical effects of the "open lung approach" with low distending pressures in acute respiratory distress syndrome. Am J Respir Crit Care Med. 1995;152:1835-46.

10. Ware L, Matthay M. The acute respiratory distress syndrome. N Engl J Med. 2000;342:1334-49.

11. Vieira SRR, Fialkow L, Plotnik R. Monitorização da mecânica respiratória na ventilação mecânica. In: Rotinas em terapia intensiva. 3ed. 2002. p.172-83.

12. Ranieri VM. Effect of mechanical ventilation on inflammatory mediators in patients with acute respiratory distress syndrome: a randomized controlled trial. JAMA. 1999;282:54-61. 
13. Rimensbereger PC, Cox PN, Frndova H. The open lung during small tidal volume ventilation: concepts of recruitment and "optimal" positive end-expiratory pressure. Crit Care Med. 1999;27:1946-52.

14. Van Der Kloot TE, Blanch L, Youngblood AM. Recruitment maneuvers in three experimental models of acute lung injury: effect on lung volume and gás exchange. Am J Resp Crit Care Med. 2000;161:1485-94.
15. Dantzker DR, Lynch JP, Weg JG. Depression of cardiac output is a mechanism of shunt reduction in the therapy of acute respiratory failure. Chest. 1980;77:636-42.

16. Villagrá A, Ochagavia A, Vatua S. Recruitment maneuvers during lung protective ventilation in acute respiratory distress syndrome. Am J Respir Crit Care Med. 2002;165:165-70.

Conflict of interest: none Financial source: CAPES

\section{Correspondence:}

Gabriel Ribeiro Mädke

R. Duque de Caxias, 1735/1404

90010-283 Porto Alegre - RS Brazil

Phone: (55 51)9115-9935

gabrielmadke@gmail.com

Received: January 15, 2008

Review: February 12, 2008

Accepted: March 18, 2008

\section{How to cite this article}

Madke GR, Pilla ES, Sanchez PG, Foernges R, Grün G, Vendrami G, Fontena E, Andrade CF, Cardoso PFG. The effects of positive end-expiratory pressure in alveolar recruitment during mechanical ventilation in pigs. Acta Cir Bras. [serial on the Internet] 2008 July-Aug;23(4). Available from URL: http://www.scielo.br/acb 